\title{
Effect of Cutting Schedule on Fodder Yield and Quality of Staggered Sown Oats
}

\author{
Harpreet Singh Dhillon and Kamaljeet Kaur Sidhu* \\ Department of Agronomy, Punjab Agricultural University, Ludhiana-141104 India \\ *Corresponding author
}

A B S T R A C T

Keywords

Fodder quality, Fodder yield, Oats

Article Info

Accepted:

20 August 2020

Available Online:

10 September 2020
Effect of date of sowing and cutting schedule on fodder yield and quality of oats was studied at two location during rabi 2016-17. Treatments comprised of 4 sowing dates $\left(10^{\text {th }} \& 25^{\text {th }}\right.$ of Oct. and Nov.) and two cutting schedules (one cut 50/60 DAS). Results revealed that crop sown on $1^{\text {st }}$ and $2^{\text {nd }}$ date gave similar fodder yield but significantly higher than the later dates. Cutting the crop 65 days after sowing produced higher fodder yield than cutting $50 \mathrm{DAS}$, though with slight deterioration in quality.

\section{Introduction}

Diversification of agriculture is desirable in view of the mounting demands for food, nutritional and environmental security and sustainability of the production system. Livestock can play an important role in this aspect. It can serve as regular source of income for small and marginal farmers besides providing cushion for overall development of agriculture. Contribution of milch animals is the highest to the GDP among the livestock sectors. India has made remarkable progress in the livestock sector after independence. Availability of milk in India increased from $130 \mathrm{~g} /$ capita/day in 1950-51 to $290 \mathrm{~g} /$ capita/day despite an increase inhuman population. Our country supports $11 \%$ of livestock population of the World with just $4.2 \%$ world's water resources and $2.3 \%$ global land. Today, India is the largest producer of milk having $146.3 \mathrm{M} \mathrm{T}$ annual production (2014-15) which was a mere 17 million tonnes in 1950. However, productivity of our milch animals is very low as compared to other parts of the globe (Gupta, 2016).

Availability of good quality fodder in sufficient quantity is one of the major bottle necks responsible for low productivity of the our livestock (Dahiya and Kharb, 2003). Area under fodder crops/grassland has been consistently disproportionate to the bovine 
population in the country. Wide gap between availability and requirement of feed and fodder needs to bridged but the chances of diverting more area for cultivation of fodder crops are remote due to stiff competition with food crops.

Oats (Avena sativa L.) is an important winter cereal crop in north-western regions of India due to congenial climate for this crop owing to its excellent growth habit and high nutritive value for all types of livestock, so its popularity as fodder crop is increasing. The oat crop is known to have high yielding potential and multicut ability

Time of sowing is one of the important yield contribution factors, which is largely, governed by temperature. It has been observed that the yield is adversely affected under very early and late sown condition. As oat crop is generally sown in month of October and November so fodder yield varies considerably owing to difference in temperature during growing season. Date of cutting oats crops as fodder is another production factor within the control of grower. Cutting very young crop as fodder gives lower fodder yield of superior quality than cutting at advanced stage.

Therefore, agronomic practices need to altered for increasing productivity and quality of fodder. Hence, an attempt has been made to study the fodder yield and quality of oats fodder crop under staggered sowing and cutting schedule.

\section{Materials and Methods}

Present investigations were conducted at two locations viz. Punjab Agricultural University, Ludhiana and its Regional Research Station, Gurdaspur during rabi 2016-17. The field experiment was laid out in randomized block design with twelve treatment combinations replicated thrice at both the locations. Combinations of 4 sowing dates (Oct. 10 \& 25 , November $10 \& 25)$ and 3 cutting schedules (No cutting, one cutting 50 or 65 days after sowing) constituted the treatments. However, results on 4 dates of sowing and 2 cutting schedules (50and 65 DAS) are reported in this manuscript. Sowing of the crop was done on the pre-scheduled dates in plots measuring $7 \times 5 \mathrm{~m}^{2}$ at Ludhiana and $5 \mathrm{X}$ $4 \mathrm{~m}^{2}$ at Gurdaspur.

Specified plots were harvested on the specified dates as fodder. Green and dry fodder yields from the net plots were recorded. Thereafter, dried samples of fodder harvested at 50 or 65 days after sowing as per treatment were subjected to the following fodder quality analysis:

Crude protein: Nitrogen content was estimated by standard Micro-Kjeldahl method. (AOAC 1990). The crude protein content (per cent) was calculated by multiplying the nitrogen per cent with a factor 6.25

Digestibility: Digestibility of fodder was determined by incubating $0.375 \mathrm{mg}$ of dry sample in the $100 \mathrm{ml}$ calibrated glass syringe filled with $30 \mathrm{ml}$ rumen liquor solution for 24 hrs at a temperature of $39^{\circ} \mathrm{C}$.

Weight of sample taken - Weight of undigested sample
Digestibility $=$ -
Weight of sample taken

Leaf stem ratio: Dry weight of leaves and stem were separated from ten plants from each plot then oven dried at $60^{\circ}$. Leaf weight was divided by stem weight to compute leaf stem ratio

Total ash: $2.5 \mathrm{~g}$ finely ground sample taken in a crucible was burnt on hot plate ignited at $600^{\circ} \mathrm{C}$ in a muffle furnace and kept in desiccators till room temperature was attained and weighed. Total ash content of the sample 
was calculated by deducting the weight of empty crucible from weight of the crucible containing ash. The ash content was expressed as total ash per centage on dry matter basis (AOAC 1990).

Net gas production (NGP): Carbon dioxide gas produced in the calibrated glass syringe due to digestion of fodder was recorded and expressed NGP/200mg

Neutral Detergent Fibre (NDF): Finally ground $0.5 \mathrm{~g}$ fodder sample was taken in Spoutless beaker and $60 \mathrm{ml}$ neutral detergent solution was added in the beaker. Then beaker was kept on hot plate for one hour. The contents were filtered through pre-weighed Gooch crucible under vacuum by giving 4-5 washings with hot distilled water and a final washing was with acetone. The crucibles were dried to a constant weight at $100^{\circ} \mathrm{C}$ and weighed.

NDF was calculated as follows:

$\mathrm{NDF}(\%)=$ Weight of oven dried crucible containing sample - weight of empty crucible
Weight of sample

Digestibility $=$
- Weight of sample taken - Weight of undigested sample
Weight of sample taken

Metabolizable energy $(\mathrm{ME})=(1.06+$ $(0.157 \times \mathrm{NGP} / 200 \mathrm{mg})+(0.0081 \times 160.7)+$ $(0.022 \times 18.33)-(0.0081 \times 100))$

Total Dissolved Solids $($ TDS $)=($ Sample weight $\times 0.97) \times(1-\%$ ash $) / 100$

Organic Matter Degraded $(\mathrm{OMD})=\mathrm{TDS}-(\mathrm{a}-$ b)

Organic Matter Digestibility $(\%)=$ OMD $\times$ 100 / TDS

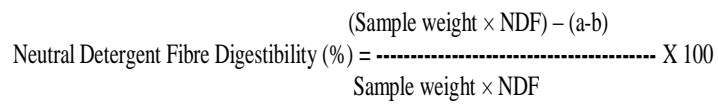

Data were subjected to statistical analysis by using CPCS1, based on the procedure suggested by Cochran and Cox (1966).

\section{Results and Discussion}

\section{Fodder yield}

\section{Green and dry fodder yield}

It is evident from the data in Table 1 that green fodder yield under influence of first two dates was significantly higher than later two dates of sowing. The difference in green fodder yield between $D_{1} \& D_{2}$ and $D_{3} \& D_{4}$ was not-significant except $\mathrm{D}_{3} \& \mathrm{D}_{4}$ for dry fodder yield.

The crop cut at 65 DAS produced significantly higher green and dry fodder yield than that cut at 50 DAS.

Interaction effect of date of sowing and cutting, presented in Table 2 dry fodder yield of crop sown on $\mathrm{D}_{1}$ and $\mathrm{D}_{2}$ cut at 50 DAS gave statistically similar yield as obtained under $\mathrm{D}_{4}$ treatment cut at 65 DAS.

Crop sown on October 25 at Gurdaspur produced higher green and dry fodder yield than all other dates of sowing. Though the difference between $D_{2} \& D_{3}$ were notsignificant.

The significant difference also existed between $\mathrm{D}_{3} \& \mathrm{D}_{4}$. Time of cutting exerted similar effect as observed at Ludhiana.

Midha et al., (1999) also reported maximum green fodder yield with cutting 80 DAS than cutting 50 DAS in oats. They attributed this to more tiller count and increased plant height. Sidhu et al., (1997) also obtained higher fodder yield of oats by delay in cutting at 90 DAS than cutting at 70 DAS. Dar et al., (2014) reported that early sowing $\left(5^{\text {th }}\right.$ 
October) significantly higher green and dry fodder yield. The higher green and dry fodder yield in case of early sowing date may be ascribed to its superiority over delayed sowing in respect to various growth attributes such as plant height, number of tillers per meter row which all were enhanced due to high temperature at early stage. Similar trend was noticed by Patel (2003) and Verma et al., (1997).

Table.1 Green and dry fodder yield of oats as affected by dates of sowing and cutting schedule at Ludhiana and Gurdaspur

\begin{tabular}{|c|c|c|c|c|}
\hline \multirow[t]{2}{*}{ Treatment } & $\begin{array}{l}\text { Green fodder } \\
\text { yield (kg/ha) }\end{array}$ & $\begin{array}{l}\text { Dry fodder yield } \\
(\mathrm{kg} / \mathrm{ha})\end{array}$ & $\begin{array}{c}\text { Green fodder } \\
\text { yield (kg/ha) }\end{array}$ & $\begin{array}{r}\text { Dry fodder } \\
\text { yield (kg/ha) }\end{array}$ \\
\hline & \multicolumn{2}{|c|}{ Ludhiana } & \multicolumn{2}{|c|}{ Gurdaspur } \\
\hline \multicolumn{5}{|l|}{ Date of sowing } \\
\hline October 10 & 10,320 & 1,393 & 10,594 & 1,478 \\
\hline October 25 & 10,319 & 1,292 & 11,055 & 1,299 \\
\hline November 10 & 6,873 & 900 & 9,242 & 1,004 \\
\hline November 25 & 6,342 & 776 & 7,776 & 778 \\
\hline $\mathrm{CD}(\mathrm{p}=0.05)$ & 950 & 120 & 1,830 & 147 \\
\hline \multicolumn{5}{|c|}{ Cutting schedule } \\
\hline Cut at 50 DAS & 5,724 & 747 & 4,955 & 670 \\
\hline Cut at 65 DAS & 11,203 & 1,434 & 14,379 & 1,607 \\
\hline $\mathrm{CD}(\mathrm{p}=0.05)$ & 670 & 91 & 1,290 & 100 \\
\hline
\end{tabular}

Table.2 Effect of date sowing and cutting schedule on dry fodder yield of oats at Ludhiana and Gurdaspur Ludhiana

\begin{tabular}{|c|c|c|c|c|}
\hline \multirow[t]{3}{*}{ Cutting schedule } & \multicolumn{4}{|c|}{ Date of sowing } \\
\hline & $D_{1}$ & $\mathbf{D}_{2}$ & $\mathbf{D}_{\mathbf{3}}$ & $\mathbf{D}_{4}$ \\
\hline & \multicolumn{4}{|c|}{ Green fodder vield (kg/ha) } \\
\hline $\mathrm{C}_{50}$ & 7,036 & 7,820 & 4,557 & 3,485 \\
\hline $\mathrm{C}_{65}$ & 13,604 & 12,818 & 9,190 & 9,200 \\
\hline $\mathrm{CD}(\mathrm{p}=\mathbf{0 . 0 5})$ & & & & \\
\hline \multicolumn{5}{|c|}{ Dry foddder yield (kg/ha) } \\
\hline $\mathrm{C}_{50}$ & 928 & 985 & 609 & 466 \\
\hline $\mathrm{C}_{65}$ & 1,859 & 1,599 & 1,190 & 1,087 \\
\hline $\mathrm{CD}(\mathrm{p}=\mathbf{0 . 0 5})$ & \multicolumn{4}{|c|}{182} \\
\hline
\end{tabular}

\section{Gurdaspur}

\begin{tabular}{|c|c|c|c|c|}
\hline \multicolumn{5}{|c|}{ Green fodder yield (kg/ha) } \\
\hline $\mathrm{C}_{50}$ & 7,300 & 6,555 & 3,151 & 2,811 \\
\hline$C_{65}$ & 13,888 & 15,555 & 15,333 & 12,740 \\
\hline $\mathrm{CD}(\mathrm{p}=0.05)$ & & & & \\
\hline \multicolumn{5}{|c|}{ Dry fodder yield (kg/ha) } \\
\hline $\mathrm{C}_{50}$ & 988 & 835 & 421 & 434 \\
\hline $\mathrm{C}_{65}$ & 1,962 & 1,763 & 1,586 & 1,113 \\
\hline $\mathrm{CD}(\mathrm{p}=0.05)$ & \multicolumn{4}{|c|}{208} \\
\hline
\end{tabular}


Table.3 Chemical composition of oats fodder as affected by dates of sowing and cutting

\begin{tabular}{|c|c|c|c|c|}
\hline Treatment & Crude protein \% & NDF,ADF etc digestibility \% & Ash \% & Leaf stem ratio \\
\hline \multicolumn{5}{|c|}{ Ludhiana } \\
\hline \multicolumn{5}{|l|}{ Date of sowing } \\
\hline October 10 & 14.87 & 77.92 & 11.0 & 1.5 \\
\hline October 25 & 16.20 & 79.16 & 10.5 & 1.6 \\
\hline November 10 & 16.87 & 81.08 & 10.3 & 1.8 \\
\hline November 25 & 18.98 & 83.75 & 9.9 & 2.2 \\
\hline CD $(p=0.05)$ & 1.19 & 1.36 & 0.4 & 0.4 \\
\hline \multicolumn{5}{|l|}{ Time of cutting } \\
\hline Cut at 50 DAS & 19.28 & 65.22 & 9.8 & 2.2 \\
\hline Cut at 65 DAS & 14.17 & 60.93 & 11.1 & 1.3 \\
\hline $\mathrm{CD}(\mathrm{p}=\mathbf{0 . 0 5})$ & 0.84 & 2.1 & 0.3 & 0.31 \\
\hline \multicolumn{5}{|c|}{ Gurdaspur } \\
\hline \multicolumn{5}{|l|}{ Date of sowing } \\
\hline October 10 & 18.79 & 79.17 & 11.5 & 1.5 \\
\hline October 25 & 19.40 & 79.96 & 11.3 & 1.7 \\
\hline November 10 & 20.26 & 80.98 & 10.9 & 2.0 \\
\hline November 25 & 21.36 & 81.38 & 10.7 & 2.4 \\
\hline CD $(p=0.05)$ & NS & 1.32 & 0.5 & 0.3 \\
\hline \multicolumn{5}{|l|}{ Cutting schedule } \\
\hline Cut at 50 DAS & 22.04 & 81.53 & 10.7 & 2.4 \\
\hline Cut at 65 DAS & 17.87 & 79.21 & 11.6 & 1.4 \\
\hline CD $(p=0.05)$ & 1.37 & 0.93 & 0.3 & 0.2 \\
\hline
\end{tabular}

Table.4 Chemical composition of oats fodder as affected by date of sowing and cutting schedule at Ludhiana and Gurdaspur

\begin{tabular}{|c|c|c|c|c|c|}
\hline \multicolumn{6}{|c|}{ Ludhiana } \\
\hline & & \multicolumn{3}{|c|}{ In vitro digestibility $(\%)$ of } & \multirow[b]{2}{*}{ ME MJ/kg DM } \\
\hline Treatment & NGP/200 mg & DM & NDF & OM & \\
\hline \multicolumn{6}{|l|}{ Date of sowing } \\
\hline October 10 & 34.56 & 77.92 & 59.74 & 76.78 & 7.31 \\
\hline October 25 & 38.08 & 79.16 & 60.97 & 78.10 & 7.90 \\
\hline November 10 & 38.66 & 81.08 & 63.14 & 79.27 & 8.05 \\
\hline November 25 & 39.96 & 83.75 & 69.06 & 82.67 & 8.34 \\
\hline $\mathrm{CD}(\mathrm{p}=\mathbf{0 . 0 5})$ & 3.56 & 1.36 & 3.0 & 1.34 & 0.31 \\
\hline \multicolumn{6}{|l|}{ Cutting schedule } \\
\hline Cut at 50 DAS & 40.02 & 81.83 & 65.22 & 80.71 & 8.30 \\
\hline Cut at 65 DAS & 35.61 & 79.12 & 60.93 & 77.70 & 7.50 \\
\hline $\mathrm{CD}(\mathrm{p}=\mathbf{0 . 0 5})$ & 2.53 & 0.96 & 2.1 & 0.94 & 0.22 \\
\hline \multicolumn{6}{|c|}{ Gurdaspur } \\
\hline \multicolumn{6}{|l|}{ Date of sowing } \\
\hline October 10 & 33.18 & 79.17 & 61.62 & 77.68 & 5.48 \\
\hline October 25 & 37.19 & 79.96 & 61.50 & 78.05 & 6.58 \\
\hline November 10 & 37.55 & 80.98 & 63.36 & 80.34 & 7.31 \\
\hline November 25 & 39.15 & 81.38 & 67.53 & 82.24 & 8.33 \\
\hline $\mathrm{CD}(\mathrm{p}=0.05)$ & 0.57 & 1.32 & 3.27 & 1.13 & 1.38 \\
\hline \multicolumn{6}{|l|}{ Cutting schedule } \\
\hline Cut at 50 DAS & 38.84 & 81.53 & 65.53 & 80.91 & 7.38 \\
\hline Cut at 65 DAS & 34.70 & 79.21 & 61.47 & 78.26 & 6.47 \\
\hline $\mathrm{CD}(\mathrm{p}=0.05)$ & 0.40 & 0.93 & 2.31 & 0.80 & NS \\
\hline
\end{tabular}




\section{Fodder quality}

Data in Table 3 reveal significant reduction in fodder quality in form of crude protein, dry matter digestibility, leaf stem ratio, neutral detergent fiber digestibility, organic matter digestibility, net gas production and metabolizable energy was observed at both the locations Ludhiana and Gurdaspur. Contrary to this ash content in fodder decreased due to delay in sowing and cutting. Improvement in crude protein content with delay in sowing could be attributed due to more succulence of the fodder. Ascending pattern of crude protein with subsequent delay in sowing might be due to dilution effect of nitrogen as the dry matter yield reduced with delay in sowing.

\section{Digestibility (In-vitro)}

Positive effect of delay in sowing on IVDMD may be due to fact that the late sown crop remains the more succulent for long period. As the rate of various physiological processes occurring in plant is directly proportional to prevalent environment condition. The plant growth was slowed down due to low temperature.

Improvement in the IVDMD digestibility of $\mathrm{DM}, \mathrm{NDF}$, and OM also followed the same trend. Net gas production (NGP) is higher in late sown crop. This might be due to lower cell wall fractions of digestion of fodder mixture and directly proportion to digestibility.

Metabolic energy (ME) it is obvious that better quality fodder produced under late sowing resulted in production of more ME.

\section{Leaf stem ratio}

As discussed in the section on plant growth plant height governed by auxin level of plant.
Rate of auxin biosynthesis is directly proportional to temperature. So higher temperature prevalent at earlier dates of sowing might have enhanced auxin biosynthesis leading to more plant height.

The promotion of leaf production might be more than stem elongation under later dates of sowing causing improvement in leaf stem ratio. Marten et al., (1988) opinioned that leaves may have two to three times the protein content of stems and more succulent than the stem. Its seem that better quality fodder in terms of crude protein, IVDMD and was resulted in improvement of leaf stem ratio under late sowing.

Fodder cut at 50 DAS had significantly higher crude protein, dry matter digestibility, neutral detergent fiber digestibility, organic matter digestibility, net gas production and metabolizable energy and leaf stem ratio than that cut at 65 DAS. Crude protein is a product of a factor 6.25 and nitrogen content. Nitrogen content in the fodder of old age decreased due to dilution effect hence reduction in crude protein was also observed. As the plant grows in age lignifications of the cell wall increase and succulence decreased. Lignin is less digestible than cellulose and hemicelluloses which might have lower the digestibility of DM, NDF, OM coupled with reduction of NGP and ME. Similar results were observed at both the locations (Table 4).

The ascending pattern of crude protein with subsequent delay in sowing might be due to lower cell wall. The digestibility parameters of nutrients were higher in late sown crop and date of cutting affected in vitro digestibility parameters inversely. Late sown crop had advantage of lower temperature during growing season which reduces the cell wall an lignifications of plant. These changes increases the digestibility, the NGP ( $\mathrm{mg} /$ nitrogen) and metabolizable energy 
Malik et al., (2015) concluded that crude protein and in vitro dry matter digestibility content in fodder decreased significantly with each delayed cutting ranging from 50 to 70 DAS. Bhilare and Joshi (2007) recorded that crude protein and digestibility were significantly higher when cut was taken at 50 DAS than that cut at 60 DAS. Hussain et al., (2004) observed that forage yield and crude fiber increased while crude protein content decreased with advancement in maturity. Sharma et al (2001) observed that crop harvested for forage at 65 DAS recorded significantly higher leaf stem ratio than cut at 85 DAS.

\section{References}

AOAC (1990) Official Methods of Analysis $\left(15^{\text {th }}\right.$ Ed.) Association of Official Agricultural Chemists, Washington DC.

Dahiya B S and Kharab R P S (2003) Fodder seed production-constraints and strategies. Forage Res., 29: 10-17.

Dar N A, Singh K N, Ahmad L, SofiJ A, Bhat M E and Kotru R (2014) Influence of dates of sowing, cultivars and different fertility levels on fodder oat (Avena sativa L.) under temperate conditions of Kashmir valley (India). Range Manage Agrof., 35: 51-55.

Gupta H S (2016) Ushering $2^{\text {nd }}$ green revolution in India: challenges and way forward. Keynote lecture: proceeding fourth national symposium on transforming Indian agriculture towards food and nutritional security, held at IGFRI Jhansi (UP) 20-21 Feb 2016. Pp. $1-5$.

Hussain A, Khan S and Mohammad D (2004) Clipping of oats at various intervals on herbage yield, forage quality and seed yield. Pakistan J Agric Res., 18: 72-75.

Malik P, Midha L K, Arya S and Joshi U N (2015) Effect of cutting and fertility levels on quality of oat. Forage Res., 40: 257-58.

Midha L K, Panwar K S and Sharma S K (1999) Effect of cut frequency and time of nitrogen application on yield and quality of oat (Avena sativa). Forage Res., 25: 99-02.

Patel T U, Arvadia M K, Malik P K, Patel D D and Patel P S (2011) Productivity of oat (Avena sativa) under different cutting management and split application of nitrogen. Indian J Agron., 56: 164-67.

Sharma S K, Bhunia S R and Yadava D K (2001) Response of oat (Avena sativa L.) to cutting management, method of sowing and nitrogen. Forage Res., 27: 167-70.

Verma S S, Singh V and Joshi Y P (1997) A short note on the seed production of wheat (VL 616) and oat (UPO-94) under different cutting management. Forage Res., 22(4): 295-97.

\section{How to cite this article:}

Harpreet Singh Dhillon and Kamaljeet Kaur Sidhu. 2020. Effect of Cutting Schedule on Fodder Yield and Quality of Staggered Sown Oats. Int.J.Curr.Microbiol.App.Sci. 9(09): 2935-2941. doi: https://doi.org/10.20546/ijcmas.2020.909.361 